\title{
水銀陰極電解分離法を用いる金属ジルコニゥムおよび 金属チタン中の極微量コバルトの比色定量
}

\author{
水池敦, 平野 四蔵*
}

少截の水銀茄陰極として試料の硫酸酸性溶液を電解し, 主成分のジルコニウムまたはチタン苍電解液 中に残し，数 $\gamma$ 程度存在するコバルトを陰極に析出させる。つぎに水銀点電解槽から石英ボートに移し 電気炉中で約 $350^{\circ} \mathrm{C}$ に加熱, 水銀点蒸溜除去したのち, ボート内残渣中のコバルトをニトロソ R塩法で 比色定量する。乙の原理にもとづく微量元素の分離濃縮方法に関する研究は従来非常に少なく, とくに 数 $\gamma$ 程度の極微量元素の場合については電解捕集率, 電解後の諸操作における損失の有無など全く不明 であつた．著者らは ${ }^{60} \mathrm{Co}$ をトレーサーとして使用して，三，三の検討觉扣てない，ほぼ淽足す心゙き分離 定量方法を得るととができた。

\section{1 緒落}

少虽の水銀老䧔極として試料の酸性溶液它電解し, 主 成分注電解液中に残し, 微量重金属不純物元素の多水 銀中に捕等したのち水銀を苲溜除去与る分離方法法，高 純度物質中の極微量重金属不純物の分離濃縮の手段之し てきわめてすぐれたものと考光られるが，研究がいまだ 比較的少なく1 年) とくに $10 \gamma$ 程度以下の不純物の分離 については实験がほとんど行わ机ておらず，電解，水銀 蒸溜などの渚操作の際に抢ける被定量元素の損失の有無 など検討すべき点が多く残されている。著者らは金属シ ルコニウム沶よび金属チタン中に数 ppm 程度以下の極 微量存在与るコバルトの定量にこの方法を応用し, 放射 性同位元䕀 ${ }^{60} \mathrm{Co}$ を使用して回収率, 電解捕集速度なぞ につき，二，三の众讨を行い，ほぼ渶足すべき分析方法 を得ることができたのでその結果を報告する。

\section{2 装置, 試薬}

\section{$2 \cdot 1$ 装 置}

（1）ガラス製電解槽: Fig. 1

(2) 電解仃電源: 東宗光電研究所製, 磁気水銀陰極 電解装置 (ANA 3 型)を利用した。 これはセレン整流器 による全波整流回路だけで沪波回路は持つていない。

（3）水銀莪溜装置 : Fig. 2

（4）光雷比色竍 : 平間式光電比色計 II 型.

（5）放射能测定装置：Nuclear-Chicago 製指向型 シンチレーション・カウンター(128 進スケーラー付) お

* 東京大学工学部工業分析化学教室 : 文京区本富士町

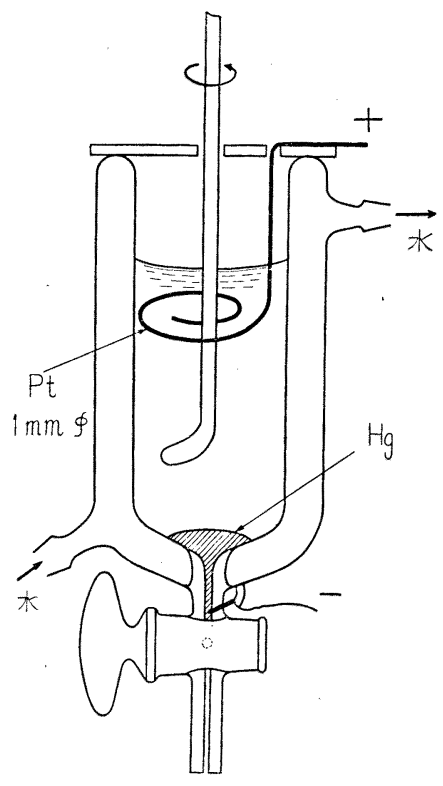

Fig. 1 ガラス製電解槽

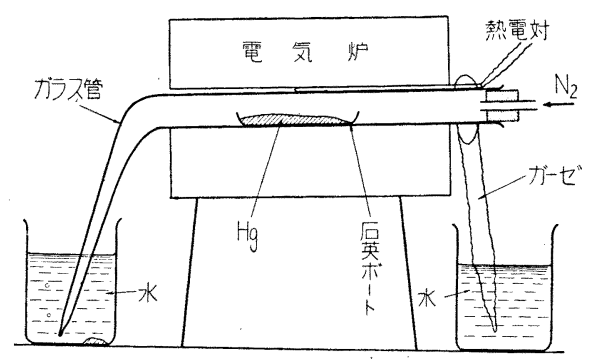

Fig. 2 水銀蒸溜装置 
よび科学研究所製井戸型シンチレーション・カウンター (100 進スケーラ一付).

\section{$2 \cdot 2$ 試 薬}

（1）水:オルガノ式モノベッド純水製造装置によっ て精製.

(2) 硫酸 : 特級.

（3）王水: 特級塩酸および硝酸より作製.

(4) クエン酸溶液 : $0.2 M$ 水溶液.

（5）緩衝液: 磞酸 $3.1 \mathrm{~g}$, 燐酸水素二ナトリウム二 水塩 $17.8 \mathrm{~g}$ を $1 N$ 水酸化ナトリウム水溶液 $250 \mathrm{ml}$ に溶 解し，水を加えて全量を $500 \mathrm{ml}$ にする.

(6) ニトロソ $\mathrm{R}$ 塩溶液 $: 0.2 \%$ 水溶液.

(7) 硝酸 : 特級, $1: 1$.

（8）コバルト標準液：ベルギー製金属コバルトを希 塩酸で溶解して作製. $1 \mathrm{~m} l$ 中にコバルト $5.0 \gamma$ を含む.

(9) ${ }^{60} \mathrm{Co}$ 標準液：上記コバルト標準液に米国から輸 入した ${ }^{60} \mathrm{Co}$ 塩酸溶液を添加して作製. 比色定量の結果, 本標準液 $1 \mathrm{~m} l$ 中にはコバルト $5.1 \gamma$ 它含えでいた.

（10）水銀：空気酸化, 硝酸洗滌, 水洗滌, 真空蒸溜 を行つて精製。

\section{3 実験方法}

\section{$3 \cdot 1$ 試料の溶解（電解液の調製）}

金属ジルコニウムの場合には, 試料削片 $1 \mathrm{~g}$ を $300 \mathrm{ml}$ テレックス製ビーカー中に入れ硫酸 $25 \mathrm{ml}$ を加光，さら に少量の水を添加しつつ砂浴上で加熱して溶解せしめ る. 完全に溶解したのち過剩の硫酸を追出すため加熱を つづけ乾固近くに至らせる.つぎに $1 N$ 硫酸を加えて再 溶解し $100 \mathrm{~m} l$ の電解液花得る.

金属チタンの場合には, 試料㹸片 $1 \mathrm{~g}$ を $300 \mathrm{ml}$ テレ ックス製ビーカー中に入れ，水少量および硫酸 $5.1 \mathrm{ml}$ を加え, 加熱して完全に溶解したのち水を加えて液量を $100 \mathrm{~m} l$ としこれを電解液とする。

\section{2 水銀陰極電解}

Fig. 1 の電解槽に水銀 $2 \mathrm{~m} l$ および上記電解液 $100 \mathrm{~m} l$ を入れ，水冷，攪拌を行いつつ電解寸る。電解条件はつ ぎのごとくである. 電流 $2 \mathrm{~A}$, 陰極電流密度 $0.5 \mathrm{~A} / \mathrm{cm}^{2}$, 電圧約 $7.5 \mathrm{~V}$, 電解時間 3 時間.

電解終了時には, 電流を断つことなく電解槽下部のコ ックをわずかに開いて大部分の水銀を $50 \mathrm{~m} l$ ビーカーに 取出す．封入白金線附近に水銀が達したときに一旦コッ クを閉じ，電流を切ってから残りの水銀を同じビーカー に採取する.最後にコックを全開してわずかに残ってい
る水銀を電解液とともに沪紙上に受け, 液を吸取らせた のち水銀のみを同じビーカーに移す。

\section{3 水銀の蒸溜除去}

ビーカー中の水銀を石英製ボートに移し，Fig. 2 の装 置で窒素を通じつつ約 $350^{\circ} \mathrm{C}$ で水銀を苲溜除去する. 水銀が蒸発し終ると同時に加熱をやめ，冷却後ゴム栓を 取外し，ガラス管壁の水銀滴のボートへの附着をさける ため,ガラス管入口から紙を丸めたものを挿入したのち， このなかを通してボートを取出す. 内容物を飛散させぬ よう注意しつつ, 王水 $5 \mathrm{~m} l$, 水少量によつてボート内残 椬を完全にもとのビーカーに移す。この際ポリスマンを 使用する.ビーカーを湯浴上に移して加熱, 残椬を溶解 しつづいて乾固する。

\section{4 コバルトの比色定量}

上記ビーカー中に水 $2.5 \mathrm{~m} l$, クエン酸溶液 $1.0 \mathrm{ml}$ を 加えて残椬を溶解寸る。この際必要があれば湯浴中で加 熱する. 次に緩衙液 $1.2 \mathrm{ml}$ 老加え $\mathrm{pH} 7.8 \sim 8.0$ に調 節する.クレゾール・レッド試駼紙で試験する。これに ニトロソ $\mathrm{R}$ 塩溶液 $0.5 \mathrm{~m} l$ を加え晹浴中で 3 分間加熱し 暗所で泠却する. 硝酸 (1: 1) $2.0 \mathrm{~m} l$ を加え晹浴中で 4 分間加熱し再び暗所で泠却したのち液量炎 $10 \mathrm{ml}$ にし*,

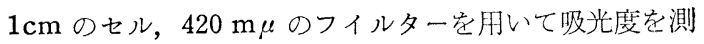
定し，あらかじめ作製しておいた検量線によつてコバル ト $\gamma$ 数を得る。

なお本実験における湯浴は，すべて $100 \mathrm{ml}$ ビーカー 中で水を沸騰直前（わずかに泡の出る程度）に保ち，こ のなかに $50 \mathrm{ml}$ ビーカーをつけて行つた。

\section{5 放射能測定}

以上 3.4 までで全分析操作を終るが，試料溶解時にト レーサーとして ${ }^{60} \mathrm{Co}$ 標準液を添加した茨合には, 比色 定量後の全溶液(セルを充分洗滌し洗液を全部加える)を $50 \mathrm{ml}$ ビーカーに移し適宜浱縮したのち, ガラス容器に 入れ $15 \mathrm{ml}$ の溶液として指向型シンチレーション・カウ ンターでその放射能を測定した。别に等量の ${ }^{60} \mathrm{Co}$ 標準 液に直接比色試薬を加えた $15 \mathrm{ml}$ の溶液を作り同時にこ の放射能を測定し，これら二つの值を比較して ${ }^{60} \mathrm{Co} の$ 回收率安求めた。

また電解中における液中コバルト濃度の変化を求める ためには, あらかじめ電解液中に ${ }^{60} \mathrm{Co}$ 標準液を添加し ておき,電解中時々液を 1 ～ $2 \mathrm{ml}$ ずつピペットで取出し，

*にごりが認められた場合には, 乾燥沪紙で沪過した のち吸光度测定を行う. 
おのおの小型試験管に入れ井戸型シンチレーション・カ ウンターによつてその放射能を測定した.

\section{4 実験結果および考察}

\section{$4 \cdot 1$ コバルト比色定量法についての検討}

比色方法は Sandell の著書6)の方法によつたが，測 定值のバラツキがやや大きかったので, 前記 (3.4) のよ うに, 加熱, 硝酸添加の方法など改良して用いほぼ満足 すべき結果を得ることができた，定量誤差は 0〜10 rの 範囲で $\pm 0.1 \gamma$ 程度である. また $2 \mathrm{mg}$ 以下の鉄, $1 \mathrm{mg}$ 以下の銅, ニッケル, マンガン, チタン, ジルコニウム, 水銀などの共存はコバルトの比色定量に汭なんらの妨害 もあたえない。

\section{$4 \cdot 2$ 金属ジルコニゥム中の極微量コバルトの定量}

金属ジルコニウム試料(国産)，およびこれに既知量の ${ }^{60} \mathrm{Co}$ 標準液を試料溶解時に添加したものを本法で定量 した結果を Table 1 に示す. 実験 1，2，3 はいわゆる

Table 1 金属ジルコニウム中のコバルト定量結果

\begin{tabular}{|c|c|c|c|c|c|}
\hline \multicolumn{2}{|c|}{$\begin{array}{l}\text { ジルコニウム } \\
\text { 採取量 } \mathbf{g}\end{array}$} & \multirow{2}{*}{$\begin{array}{c}\begin{array}{c}\text { コバルト添 } \\
\text { 加量 } \gamma(\mathrm{A})\end{array} \\
0\end{array}$} & \multirow{2}{*}{ 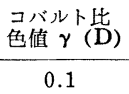 } & \multirow{2}{*}{$\frac{(\mathrm{D})-(\mathrm{A})}{\gamma}$} & \multirow{2}{*}{$\frac{\begin{array}{c}{ }^{60} \mathrm{Co} \\
\text { 率 } \%\end{array}}{-}$} \\
\hline 1 & 0 & & & & \\
\hline 2 & 0 & 1.0 & 1.3 & 0.3 & $93 \pm 3$ \\
\hline \multirow[t]{2}{*}{3} & 0 & 5.1 & 5.4 & 0.3 & $99 \pm 2$ \\
\hline & & & & \multicolumn{2}{|c|}{ 平均 0.2 (空諤験值) } \\
\hline 4 & 1.00 & 0 & 0.7 & 0.7 & - \\
\hline 5 & 1.00 & 1.0 & 1.8 & 0.8 & $99 \pm 3$ \\
\hline 6 & 1.00 & 5.1 & 5.9 & 0.8 & $99 \pm 2$ \\
\hline \multirow[t]{2}{*}{7} & 1.00 & 5.1 & 5.9 & 0.8 & $98 \pm 2$ \\
\hline & & & & 平均 0.8 & \\
\hline
\end{tabular}

空試験に相当するもので, 試薬量, 操作とも本実験とで き得るかぎり同じにして行つたものである．放射能測定 によるコバルト回収率は大部分 $98 \%$ 以上であり，また (D)一(A)の值が試料, 空試験ともほぼ一定值を示すこ とから，本定量法が金属ジルコニウム中の数 $\gamma$ 程度の極 微量コバルトに対して满足すべきものであることがわか る. またこの実験に用いた金属ジルコニウム中のコバル ト含有量は $0.6 \mathrm{ppm}$ となるが，空試験值がやや大きい ためこの值の信頼度は幾分低いと思われる. 空試験值の 減少, 試料採取量の增加によつてさらに正確な分析值が 得られるはずである。

\section{$4 \cdot 3$ 金属チタン中の極微量コバルトの定量}

金属チタン試料(国産), およびこれに試料溶解時に既 知量の ${ }^{60} \mathrm{Co}$ 標準液を添加したものを本法で定量した結 果を Table 2 に示す. 実験 1 は空試験である. ${ }^{60} \mathrm{Co}$ 回
収率はほとえど 100\%，(D)一（A)が一定值を示すこと から，この場合にも金属ジルコニウムの場合と同じく本 方法が満足すべき結果をあたえることがわかる。なお本 実験に用いた金属チタン中のコバルトは $0.5 \mathrm{ppm}$ とな る.

Table 2 金属チタン中のコバルト定量結果

\begin{tabular}{|c|c|c|c|c|c|}
\hline & $\begin{array}{l}\text { チタン } \\
\text { 採取量 } \mathrm{g}\end{array}$ & $\begin{array}{l}\text { コバルト } \\
\text { 添加量 } \gamma(\mathrm{A})\end{array}$ & $\begin{array}{l}\text { コパルト } \\
\text { 比色値 } \gamma(\mathrm{D})\end{array}$ & (D) $\frac{-(A)}{\gamma}$ & ${ }^{60} \mathrm{Co}$ 回收率 \\
\hline 1 & 0 & 1.0 & 1.4 & 0.4 (空試験值) & 直) $101 \pm 3$ \\
\hline 2 & 1.00 & 0 & 0.9 & 0.9 & - \\
\hline 3 & 1.00 & 1.0 & 2.0 & 1.0 & $99 \pm 3$ \\
\hline 4 & 1.00 & 2.0 & 2.8 & 0.8 & $100 \pm 3$ \\
\hline 5 & 1.00 & 5.1 & 6.0 & 0.9 & $100 \pm 2$ \\
\hline & & \multicolumn{4}{|c|}{ 平均 0.9} \\
\hline
\end{tabular}

\section{4 極微量コバルトの電解捕集速度}

電解時における極微量コバルトの捕集状況を, ${ }^{60} \mathrm{Co}$ を トレーサーとして求めた結果を Fig. 3, Fig. 4, Fig. 5

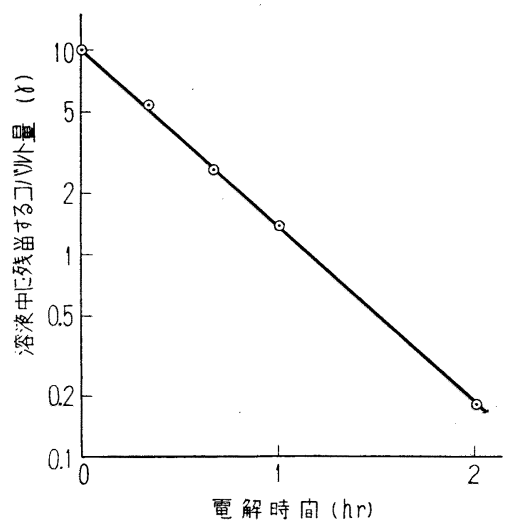

Fig. 3 電解捕集曲線

電解波 : $100 \mathrm{~m} l, 1 N$ 硫酸酸生, コバルト $10 \gamma$ 合有. $7.5 \mathrm{~V}, 1.9 \mathrm{~A}$. $\mathrm{T}_{1 / 2}=21 \mathrm{~min}$.

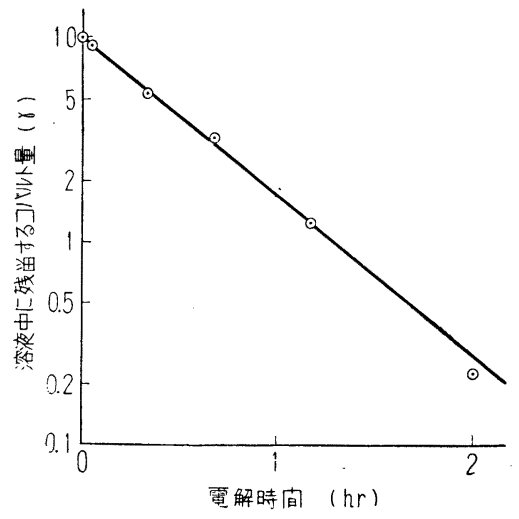

Fig. 4 電解捕集曲線

電解液 : $100 \mathrm{~m} l, 1 \mathrm{~N}$ 硫酸酸生, $\mathrm{Zr}\left(\mathrm{SO}_{4}\right)_{2}$ を $\mathrm{Zr}$ として $1 \mathrm{~g}$ およびコバルト $10 \gamma$ 合有. $7.5 \mathrm{~V}, 1.9 \mathrm{~A}$. $\mathrm{T}_{1 / 2}=23 \mathrm{~min}$. 


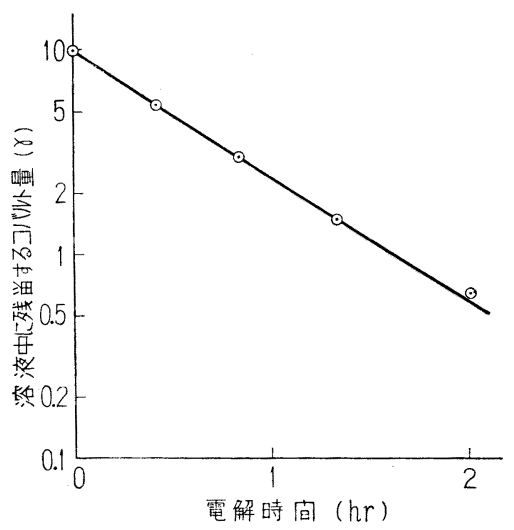

Fig. 5 電解捕集曲線

電解液: $100 \mathrm{ml}, 1 \mathrm{~N}$ 硫酸酸性, $\mathrm{Ti}\left(\mathrm{SO}_{4}\right)_{2}$ を $\mathrm{Ti}$ として $1 \mathrm{~g}$ およびコバルト $10 \gamma$ 含有. $7.2 \mathrm{~V}, 2.1 \mathrm{~A} . \mathrm{T}_{1 / 2}=29 \mathrm{~min}$.

に示す、いずれも時刻 0 (電解開始時) および $t$ におけ る液中コバルト量をそれぞれ $C_{0}, C$ とすると液中コバ ルト量の変化は (1) 式であらわされる.

$$
C=C_{0} e^{-\frac{\ln 2}{T_{1 / 2}} t}
$$

ここに $T_{1 / 2}$ は常数で，液中コバルト量が半滅するに 要する時間に相当する．この直線を外插して電解開始後 $6 T_{1 / 2}$ 経つたときには液中コバルト量は最初の $2 \%$ 以下 になることが予想されるが，事実 Table 1, Table 2 に示されるごとく 3 洔間後にはコバルトの $98 \%$ 以上が 水銀中に捕集されている。

なお (1) 式は電極界面におけるコバルトの拡散, 泳動 を律速段階と考光た場合の理諭式と一致しており，また $T_{1 / 2}$ は硫酸溶液, ジルコニウム溶液, チタン溶液の順に 大きくなつていることが認められるが, これら電解析出 の機構に関連した諸問題についてはさらに研究艺行いつ つあるので，追ってまとめて報告する予定である。

\section{5 絓論}

金属ジルコニウムまたは金属チタン中に数 $\mathrm{ppm}$ 程度 以下の極微量存在するコバルトを，水銀除極電解法で分 離濃縮したのち，ニトロソ $\mathrm{R}$ 塩法によつて比色定量する 方法定研究した。 ${ }^{60} \mathrm{Co}$ をトレーサーとして使用し，コ
バルトの回収率，電解捕集速度などの測定を行い，この 方法によつて数 $\gamma$ 程度以下のコバルトを $\pm 0.1 \gamma$ 程度の 誤差で分離定量できることを確めた。

（昭和 32 年 10 月，日本分析化学会第 6 年会講演）

\section{交献}

1) N. H. Furman, C. E. Bricker, B. McDuffie: J. Wash. Acad. Sci., 38, 159 (1948).

2) C. J. Rodden: "Analytical Chemistry of the Manhattan Project", 520 (1950), (McGrawHill Book Co., New York).

3) H. Coriou, J. Guéron, H. Hering, P. Léveque: J. chim. phys., 48, 55 (1951); C. A., 45, 6940 (1951).

4) W. E. Schmidt, C. E. Bricker: J. Electrochem. Soc., 102, 623 (1955).

5) C. J. Sambucetti, E. Witt, A. Gori: Proc. Intern. Conf. Peaceful Uses Atomic Energy, Geneva, 8, 266 (1956).

6) E. B. Sandell: "Colorimetric Determınation of Traces of Metals", 2nd Ed., 274 (1950), (Interscience Publishers, New York).

$$
\stackrel{\lambda}{n}
$$

Colorimetric determination of trace amounts of cobalt in zirconium and titanium metal using mercury-cathode electrolysis. Atsushi Mizuike and Shizo Hirano (Faculty of Engineering, University of Tokyo)

An electrolytic separation has been applied to the photometric determination of microgram quantities of cobalt in zirconium and titanium metal. A sulfuric acid solution containing $1 \mathrm{~g}$ of the metals is electrolyzed with $2 \mathrm{ml}$ of mercury as the cathode and a platinum spiral as the anode. The conditions of electrolysis are as follows: current strength, $2.0 \mathrm{amp}$; current density, 0.5 $\mathrm{amp} / \mathrm{cm}^{2}$; electrolyte volume, $100 \mathrm{ml}$; acidity, $1.0 \mathrm{~N}$; time of electrolysis $3 \mathrm{hr}$. After electrolysis the mercury is drained out, distilled in a stream of nitrogen at $350^{\circ} \mathrm{C}$, and the cobalt in the residue is determined by the photometric nitroso-R salt method. Tracer experiments using cobalt- 60 indicate an exponential decrease in cobalt concentration of the electrolyte during the electrolysis, and an almost perfect recovery of cobalt under the prescribed conditions. One tenth to $5 \mathrm{ppm}$ of cobalt can be determined with an accuracy of $0.1 \mathrm{ppm}$. (Received Apr. 22, 1958) 